\title{
Implementasi Metode Naive Bayes Classifier Untuk Klasifikasi Status Gizi Stunting Pada Balita
}

\author{
Monica Yoshe Titimeidara ${ }^{a}$, Wiwien Hadikurniawati ${ }^{b}$ \\ ${ }^{a}$ Universitas Stikubank, Jl. Tri Lomba Juang No.1, Semarang 50241, Indonesia \\ ${ }^{b}$ Universitas Stikubank, Jl. Tri Lomba Juang No.1, Semarang 50241, Indonesia
}

\section{INFORMASI ARTIKEL}

Sejarah Artikel:

Diterima Redaksi: 16 Mei 2021

Revisi Akhir: 17 Juni 2021

Diterbitkan Online: 17 Juni 2021

\section{KATA KUNCI}

Klasifikasi

Stunting

Naive Bayes Classifier

\section{KORESPONDENSI}

E-mail: 222monicayoshe@gmail.com

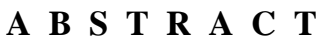

\begin{abstract}
Stunting describes a state of chronic malnutrition during growth and development since early life. This situation is represented by the height $\mathrm{z}$-score for age $(\mathrm{TB} / \mathrm{U})$, which is less than minus 2 standard deviations (SD), based on WHO growth standards.Data from the Semarang City Health Office stated that the results of monitoring nutritional status based on indicators of body length for age $(\mathrm{PB} / \mathrm{U})$ or height for age $(\mathrm{TB} / \mathrm{U})$ the incidence of stunting in the city of Semarang was $20.37 \%$. This research will make it easier to determine information regarding the classification of stunting nutritional status in toddlers. Stunting data will be processed and used as information regarding normal or not stunting nutritional status in toddlers. With this information, it can make it easier to collect data on toddlers who experience stunting nutritional status, besides that it can also be used to hold counseling to increase stunting nutritional levels and prevent stunting in toddlers by using the Naive Bayes Classifier. The accuracy result of the Naive Bayes Classifier method in classifying stunting nutritional status is $88 \%$
\end{abstract}

\section{PENDAHULUAN}

Usia balita lebih membutuhkan asupan gizi yang cukup dalam segi kuantitas dan kualitas, karena anak usia dini biasanya memiliki aktifitas fisik yang cukup tinggi karena masih dalam proses belajar [1]. Pembangunan kesehatan di Indonesia dari tahun 2015 sampai dengan 2020 dititikberatkan pada 3 komponen pokok yaitu penekanan tingkat mortalitas ibu dan bayi, penurunan stunting, pencegahan penyakit menular dan tidak menular. Upaya peningkatan status gizi masyarakat, termasuk menurunkan angka kejadian stunting atau stunting pada balita, tercatat sebagai salah satu prioritas pembangunan nasional yang tercantum dalam tujuan utama rencana pembangunan jangka menengah. Salah satu masalah gizi yang akan dibahas dalam penelitian ini adalah stunting.

Stunting menggambarkan keadaan kurang gizi kronis pada masa pertumbuhan dan perkembangan sejak awal kehidupan. Keadaan ini diwakili oleh tinggi badan z-score usia (TB/U), yang kurang dari minus 2 standar deviasi (SD), berdasarkan standar pertumbuhan WHO [3]. Secara global, sekitar seperempat anak balita mengalami stunting.

Gizi buruk pada bayi menyebabkan angka kematian bayi dan anak menjadi tinggi, rentan sakit dan postur badan yang buruk di masa pertumbuhannya.

Kemampuan kognitif pasien juga menurun, menyebabkan kerugian ekonomi jangka panjang bagi Indonesia. Berbeda dengan anak usia 0-24 bulan, anak usia 12-59 bulan memiliki angka kejadian stunting yang lebih tinggi. Stunting dapat memiliki efek jangka pendek dan jangka panjang.Efek jangka pendek meliputi keterlambatan perkembangan kognitif, motorik, dan bahasa, selain risiko kecacatan, penyakit menular, dan mortalitas, untuk efek jangka panjang adalah risiko penyakit degeneratif, seperti tekanan darah tinggi, diabetes, koroner. penyakit jantung, dan stroke. Dampak lebih lanjut terjadi pada masa dewasa yaitu berkurangnya efisiensi kerja [4].

Di Indonesia, menurut hasil Riset Kesehatan Dasar (Riskesdas), prevalensi stunting adalah 37,2\%, meningkat dari tahun 2019 $(35,6 \%)$ dan 2020 (36,8\%). Angka prevalensi stunting pada tahun 
2020 Kementerian Kesehatan Republik Indonesia adalah 38,9\%. Angka prevalensi stunting di Jawa Tengah sendiri adalah 33,9\%, dimana $17,0 \%$ kerdil dan 16,9\% sangat pendek. Sementara itu, data dari Dinas Kesehatan Kota Semarang menunjukkan bahwa berdasarkan hasil pemantauan status gizi panjang badan menurut umur $(\mathrm{PB} / \mathrm{U})$ atau tinggi badan menurut umur $(\mathrm{TB} / \mathrm{U})$, kejadian stunting di kota Semarang adalah 20,37\%.

Penelitian ini menggunakan data yang diambil dari Puskesmas Pandanaran. Data tersebut kemudian akan diolah dan dijadikan sebagai informasi mengenai normal atau tidaknya status gizi stunting pada balita. Dengan informasi tersebut, dapat mempermudah dalam pendataan balita yang mengalami status gizi stunting, selain itu juga dapat digunakan untuk di adakannya penyuluhan guna peningkatan taraf gizi stunting serta pencegahan mengenai stunting pada balita dengan menggunakan Naive Bayes Classifier.

Naive Bayes Classifier adalah suatu metode klasifikasi statistik dalam melakukan prediksi suatu probabilitas (kemungkinan) darianggota suatu class. Akurasi dan kecepatan metode Naive Bayes Classifier sangat tinggi ketika digunakan dalam aplikasi suatu basis data yang memiliki jumlah data yang besar. Algoritma Naive Bayes Classifierakan meminimalkan tingkat error jika dibandingkan dengan algoritma klasifikasi yang lain [5].

\section{A. Klasifikasi}

Klasifikasi merupakan proses ditemukannya fungsi atau model sebagai pembeda konsep atau kelas data yang bertujuan untuk memperkirakan kelas dari obejek yang belum diketahui[6].

\section{B. Gizi}

Gizi merupakan faktor terpenting untuk tercapainya tumbuh dan berkembangnya balita secara optimal. Gizi yang tepat sangat mendukung dalam fase periode emas pertumbuhan. Growth faltering (gagal tumbuh) dapat disebabkan apabila terjadi kekurangan gizi sehingga balita dapatberkembang menjadi anak yang lebih pendek (stunting) dari normal. Penurunan kemampuan produktivitas, kecerdasan atau meningkatnya resiko penyakit yang degeneratif pada masa yang akan datang dapat disebabkan oleh balita yang mengalami stunting. Perhatian khusus perlu didapatkan pada balita stunting dengan usia 2-3 tahun. Usia 2-3 tahun cenderung terlambat dalam proses pertumbuhan yang lebih rendah dibandingkan dengan usia 0-2 tahun [7]. Permasalahan pada stunting berhubungan dengan naiknya resiko akan kesakitan dan kematian, perkembangan otak yang kurang maksimal sehingga kemampuan motorik anak akan menjadi terlambat dan menghambattumbuh kembangnya mental pada anak balita.

\section{Data Mining}

Data mining merupakan suatu proses yang menggabungkanbebrapa metodeseperti statistik, matematika, artificial intelegence dan machine learning dalam melakukan ekstrasi dan identifikasi suatu informasi yang bergunadari berbagai basis data yang besar. Hakikat data miningsebagai disiplin ilmu yang bertujuan untuk ditermukan, digali atau ditambang suatu pengetahuan dari data atau informasi yang dimiliki. Data miningdisebut juga sebagai knowledge discoveryin database (KDD). KDD merupakankegiatan yang terdiri dari mengumpulkan, memakai data, historis untuk ditemukannya suatu keteraturan, pola atau hubungan dalam suatu data dengan ukuran yang besar [8].

D. Naïve Bayes

Naive Bayesyaitu suatumetode klaifikasi probabilistik yang sederhana untuk menghitung beberapa kemungkinan dengan dijumlahkannya frekuensi dan kombinasi nilai dari suatu dataset.Teorema Bayes diasumsikan bahwa atribut yang independent atau tidak saling bergantungakan diberikan oleh nilai pada variabel class. Arti lain dari Naive Bayes yang dikembangkan oleh Thomas Bayes (ilmuan Inggris) yaitu metode klasifikasi statistik untuk memperkirakan peluang yang akan terjadi di masa yang akan datang berdasar pengalaman dari masa yang lalu [9].

Sebagai alat pengambilan keputusan, Naive Bayes juga digunakan dalam memperbarui tingkat kepercayaan dari suatu informasi.

Teori Naive Bayes adalah salah satu cabang dari teori statistik matematik yang dimungkinkan untuk dibuat satu model ketidakpastian dari suatu kejadian pada masa akan datangyang digabungkan dengan pengetahuan umum dengan fakta dari hasil pengamatan. Statement teori Naive Bayes

$$
\mathrm{P}(\mathrm{H} \mid \mathrm{X})=\frac{P(X \mid H) P(H)}{P(X)}
$$

Dimana :

$$
\begin{array}{ll}
\mathrm{X} & =\text { Data class yang belum diketahui } \\
\mathrm{H} & =\text { Hipotesis data } \\
\mathrm{P}(\mathrm{H} \mid \mathrm{X})= & \text { Probabilitas hipotesis H berdasar kondisi } \mathrm{X} \\
\mathrm{P}(\mathrm{H}) & =\text { Probabilitas hipotesis } \mathrm{H} \\
\mathrm{P}(\mathrm{X} \mid \mathrm{H})= & \text { Probabilitas } \mathrm{X} \text { berdasarkan kondisi pada hipotesis } \\
& \mathrm{H} \\
\mathrm{P}(\mathrm{X})= & \text { Probabilitas } \mathrm{X}
\end{array}
$$

\section{TINJAUAN PUSTAKA}

Penelitian Yani Parti Astuti menghasilkan Kenaikan performa dari pengujian algoritma naïve bayes dengan pengujian optimasi forward selection terhadap algoritma naïve bayes. kemudian penelitian yang dilakukan Dewi Simanjuntak menghasilkan diagnosa penyakit dan presentase nilai probabilitas sesuai dengan Naïve Bayes Classifier

Pada penelitian Deny Wiria Nugraha menunjukan bahwa algoritma Naive Bayes Classifier dapat digunakan (valid) untuk melakukan proses klasifikasi penyakit stroke. penelitian selanjutnya dilakukan oleh Venny Lovina Gumiri menyatakan bahwa penerapan metode naive bayes dapat mengklasifikasikan status perkembangan anaka usia dini.

\section{METODOLOGI}

Analisis data pada penelitian ini menggunakan metode CRISPDM (Cross Industry Standart Process for Data Mining) yang merupakan model proses data mining dengan siklus hidup yang terbagi menjadi 6 fase yaitu meliputi pemahaman bisnis, pemahaman data, pengolahan data, pemodelan dan evaluasi seperti gambar 1 


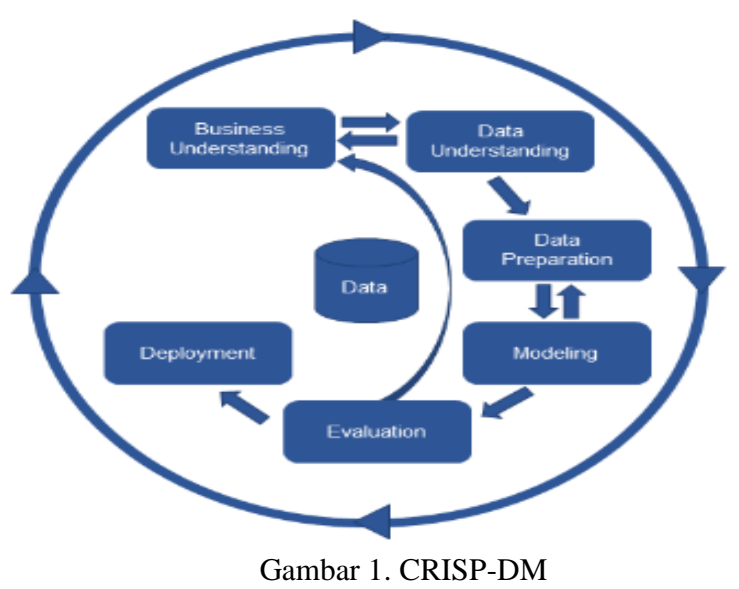

Berikut ini tahap dalam siklus hidup CRISP-DM (Cross Industry Standart Process for Data Mining) yang digunakan dalam penelitian ini yaitu

1. Pemahaman Bisnis (Bussiness Understanding) Pada tahap pemahaman bisnis dilakukan pemahaman terhadap penelitian sebagai pendukung keputusan terbaik untuk melakukan klasifikasi status gizi stunting yang diharapkan mampu melakukan penanganan terbaik terhadap balita yag mengalami status gizi stunting, sehingga dapat dilakukan langkah antisipasi yang berupa pencegahan secara dini terhadap balita yang mengalami status gizi stunting. Hal ini dilakukan untuk mencegah dan mengurangi tingkat balita yang mengalami stunting yang berakibat pada kecacatan sehingga terhambatnya perkembangan balita atau bahkan dapat mengakibatkan kematian. Pemanfaatan dataset dan penggunaan algoritma yang diusulkan maka penelitian ini akan mencapai tujuan yang telah direncanakan.

2. Pemahaman Data (Data Understanding) Tahap atau fase kedua yang dilakukan pada siklus hidup metode CRISP-DM adalah pemahaman data (data understanding). Dataset yang digunakan pada penelitian ini merupakan dataset status gizi stunting pada balita tahun 2020 yang diperoleh dari Puskesmas Pandanaran Semarang. Dataset status gizi stunting balita ini berjumlah 300 record data. Dalam dataset tersebut terdapat 5 atribut dan 1 label dengan tipe data integer dan binominal. Dari total 300 record yang ada dalam data status gizi stunting balita, dinyatakan 258 balita mengalami status gizi stunting dan 42 balita lainnya mengalami status gizi normal

3. PengolahanData(DataPreparation)

Tahap ini mengolah dataset untuk menyederhanakan data. Dataset status gizi akan di klasifikasikan sebagai berikut:

$$
\begin{array}{ll}
\text { a. } & \text { Umur (Bulan) } \\
\text { b. } & \text { Berat Badan }(\mathrm{Kg}) \\
\text { c. } & \text { Tinggi Badan }(\mathrm{Cm})
\end{array}
$$

4. Pemodelan(Modelling)

Tahap modelling dilakukan penerapan teknik pemodelan menggunakan algoritma yang akan digunakan. Pada tahap modelling dalam penelitian ini adalah klasifikasi status gizi stunting pada balita dengan menerapkan algoritma Nä̈ve Bayes Classifier. Dari hasil pemodelan tersebut akan dilakukan perhitungan akurasi menggunakan Confusion Matrix untuk mengetahui hasil akurasi yang didapatkan dan dilakukan validasi untuk mengukur performa dari algoritma.

5. Evaluasi(Evaluation)

Tahap ini adalah melakukan evaluasi dari tahap sebelumnya yaitu modelling. Tujuan dilakukannya evaluasi adalah menyesuaikan model yang didapatkan agar tepat dan sesuai dengan sasaran target yang ingin dicapai. Pada tahapan ini model yang terbentuk adalah algoritma Naïve Bayes Classifier yang akan diuji menggunakan diagram Confusion Matrix untuk mengetahui nilai akurasi yang diperoleh. Dari hasil confusion matrix itulah akan diperoleh hasil klasifikasi status gizi stunting yang benar dan yang salah serta status gizi normal yang benar dan yang salah.

\section{HASIL DAN PEMBAHASAN}

\begin{tabular}{|c|c|c|c|c|c|c|c|}
\hline No & J.Kel & Umur & BB & TB & Miskin & $\begin{array}{c}\text { Kategori } \\
\text { Status Gizi }\end{array}$ & $\begin{array}{c}\text { Status } \\
\text { Gizi }\end{array}$ \\
\hline 1 & $\mathrm{~L}$ & 22 & 4 & 55 & Ya & Normal & Stunting \\
\hline 2 & $\mathrm{~L}$ & 30 & 13 & 76 & Ya & Normal & Stunting \\
\hline 3 & $\mathrm{~L}$ & 26 & 5 & 50 & Ya & Normal & Stunting \\
\hline 4 & $\mathrm{~L}$ & 29 & 5 & 90 & Ya & Pendek & Stunting \\
\hline 5 & $\mathrm{~L}$ & 32 & 6 & 54 & Tidak & Pendek & Stunting \\
\hline 6 & $\mathrm{~L}$ & 33 & 8 & 77 & $\mathrm{Ya}$ & Pendek & Stunting \\
\hline 7 & $\mathrm{~L}$ & 39 & 7 & 100 & Ya & Pendek & Stunting \\
\hline 8 & $\mathrm{~L}$ & 24 & 8 & 80 & Tidak & Pendek & Stunting \\
\hline 9 & $\mathrm{~L}$ & 27 & 14 & 90 & $\mathrm{Ya}$ & Normal & Stunting \\
\hline 10 & $\mathrm{P}$ & 16 & 9 & 56 & Ya & Normal & Stunting \\
\hline 11 & $\mathrm{~L}$ & 2 & 16 & 96 & Tidak & Normal & Stunting \\
\hline 12 & $\mathrm{P}$ & 18 & 15 & 87 & Ya & Normal & Stunting \\
\hline 13 & $\mathrm{P}$ & 15 & 2 & 60 & Tidak & Normal & Stunting \\
\hline 14 & $\mathrm{P}$ & 10 & 3 & 88 & Tidak & Normal & Stunting \\
\hline 15 & $\mathrm{~L}$ & 7 & 8 & 98 & $\mathrm{Ya}$ & Normal & Stunting \\
\hline 16 & $\mathrm{~L}$ & 11 & 16 & 102 & Tidak & Pendek & Stunting \\
\hline 17 & $\mathrm{~L}$ & 6 & 17 & 86 & $\mathrm{Ya}$ & Pendek & Stunting \\
\hline 18 & $\mathrm{~L}$ & 5 & 3 & 60 & $\mathrm{Ya}$ & Pendek & Stunting \\
\hline 19 & $\mathrm{~L}$ & 17 & 3 & 85 & Ya & Pendek & Stunting \\
\hline 20 & $\mathrm{~L}$ & 22 & 5 & 99 & Tidak & Pendek & Stunting \\
\hline 21 & $\mathrm{P}$ & 34 & 4 & 67 & $\mathrm{Ya}$ & Pendek & Stunting \\
\hline 22 & $\mathrm{~L}$ & 37 & 9 & 98 & $\mathrm{Ya}$ & Pendek & Stunting \\
\hline 23 & $\mathrm{P}$ & 42 & 15 & 100 & Tidak & Pendek & Stunting \\
\hline 24 & P & 19 & 2 & 50 & Tidak & Pendek & Stunting \\
\hline 25 & $\mathrm{P}$ & 25 & 7 & 60 & Tidak & Pendek & Stunting \\
\hline 26 & $\mathrm{P}$ & 44 & 7 & 91 & Tidak & Normal & Stunting \\
\hline 27 & $\mathrm{P}$ & 23 & 9 & 83 & Tidak & Pendek & Stunting \\
\hline 28 & $\mathrm{P}$ & 5 & 3 & 61 & Tidak & Pendek & Stunting \\
\hline 29 & $\mathrm{P}$ & 21 & 5 & 87 & Tidak & Pendek & Stunting \\
\hline 30 & $\mathrm{~L}$ & 58 & 16 & 96 & Ya & Pendek & Stunting \\
\hline 295 & $\mathrm{P}$ & 43 & 9 & 89 & Tidak & Pendek & Normal \\
\hline 296 & $\mathrm{P}$ & 47 & 21 & 86 & $\mathrm{Ya}$ & Pendek & Normal \\
\hline 297 & $\mathrm{P}$ & 2 & 7 & 79 & Tidak & Pendek & Normal \\
\hline 298 & $\mathrm{P}$ & 6 & 15 & 80 & Tidak & Pendek & Normal \\
\hline 299 & $\mathrm{P}$ & 12 & 14 & 93 & Tidak & Pendek & Normal \\
\hline 300 & $\mathrm{~L}$ & 10 & 3 & 100 & Tidak & Pendek & Normal \\
\hline
\end{tabular}

\subsection{Tabel}

Tabel 1. Data Balita Puskesmas Pandanaran Kota Semarang

Penjelasan mengenai atribut-atribut yang terdapat dalam dataset status gizi stunting balita dijabarkan sebagai tabel 2 . 
Tabel 2. Status Gizi Stunting

\begin{tabular}{|c|c|c|c|}
\hline No & Atribut & TipeData & Keterangan \\
\hline 1. & $\begin{array}{l}\text { Jenis } \\
\text { Kelamin }\end{array}$ & Binominal & Gender (L/ P) \\
\hline 2. & Umur & Integer & $\begin{array}{l}\text { Usia balita yang } \\
\text { dinyatakan dalam } \\
\text { bulan }\end{array}$ \\
\hline 3. & $\begin{array}{l}\text { Berat } \\
\text { Badan }\end{array}$ & Integer & $\begin{array}{l}\text { Berat badan } \\
\text { balitayang } \\
\text { dinyatakan dalam } \\
\text { hitungan kilogram. }\end{array}$ \\
\hline 4. & $\begin{array}{l}\text { Tinggi } \\
\text { Badan }\end{array}$ & Integer & $\begin{array}{l}\text { Tinggi/panjang } \\
\text { badan balita } \\
\text { yangdinyatakan } \\
\text { dalam cm. }\end{array}$ \\
\hline 5. & Miskin & Binominal & $\begin{array}{ll}\text { Status } & \text { ekonomi } \\
\text { keluarga } & \end{array}$ \\
\hline 6. & Kategori & Binominal & $\begin{array}{l}\text { Kategori stunting } \\
\text { yaitu normal atau } \\
\text { pendek }\end{array}$ \\
\hline 7. & Status & Binominal & Status gizi stunting \\
\hline
\end{tabular}

Klasifikasi umur menurut $W H O$ diperlihatkan seperti tabel 3.

Tabel 3.Atribut Umur

\begin{tabular}{ll}
\hline Umur (Bulan) & Klasifikasi \\
\hline$<12$ & Bayi \\
$>12$ & Anak
\end{tabular}

Klasifikasi berat badan menurut $W H O$ diperlihatkan seperti tabel 4.

Tabel 4. Atribut Berat Badan

\begin{tabular}{ll}
\hline \multicolumn{1}{c}{ Berat Badan $(\mathbf{K g})$} & Klasifikasi \\
\hline$<2,5$ & Rendah \\
$2,5-4$ & Normal \\
$>4$ & Lebih
\end{tabular}

Klasifikasi tinggi badan menurut $W H O$ diperlihatkan seperti tabel 5 .

Tabel 5. Atribut Tinggi Badan

\begin{tabular}{ll}
\hline Tinggi Badan $(\mathbf{C m})$ & Klasifikasi \\
\hline$<85$ & Pendek \\
$85-110$ & Normal \\
$>110$ & Tinggi
\end{tabular}

Berdasarkan tabel konversi diatas, dataset pada tabel 1 diklasifikasikan seperti tabel 6.

Tabel 6. Klasifikasi Data

\begin{tabular}{lllllll}
\hline No. J.Kel & Umur & BB & TB & Miskin & $\begin{array}{c}\text { Kategor } \\
\text { i Status } \\
\text { Gizi }\end{array}$ & $\begin{array}{c}\text { Status } \\
\text { fassword salah } \\
\text { Gizi }\end{array}$ \\
\hline
\end{tabular}


Gambar 3 menjelaskan tentang halaman data yang digunakan admin untuk mengelola data status gizi stunting pada sistem ini. Isi jenis kelamin, umur, berat badan, tinggi badan, status miskin, kategori, status gizi kemudian tekan tombol simpan untuk menyimpan data status gizi stunting pada balita ke tabel data. Klik edit kemudian isi jenis kelamin, umur, berat badan, tinggi badan, status miskin, kategori, status gizi dan tekan tombol simpan untuk mengubah data status gizi stunting pada balita dari tabel data. Klik hapus kemudian pilih oke untuk menghapus data status gizi stunting pada balita dari tabel data

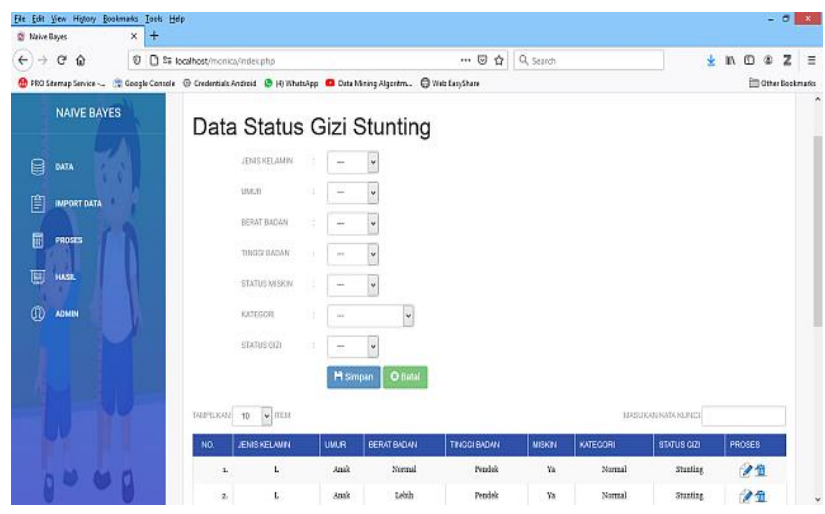

Gambar 3. Data

\section{Import Data}

Gambar 4 menjelaskan tentang halaman import data yang digunakan admin untuk mengimport data status gizi stunting dengan format excel (xls) pada balita ke sistem. Pilih file xls kemudian tekan tombol import untuk mengimport data xls ke dalam tabel data. Jika ingin mengosongkan data pada saat melakukan import data xls klik check box kosongkan data.

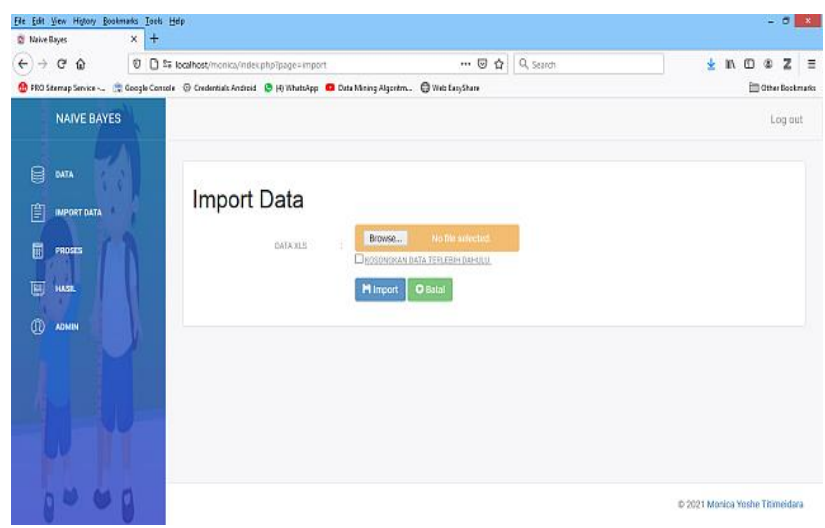

Gambar 4.Import Data

\section{Proses}

Gambar 5 menjelaskan tentang halaman proses yang digunakan admin untuk memproses klasifikasi status gizi stunting pada balita. Isi data latih yang diinginkan untuk menguji metode Naive Bayes Classifier kemudian klik tombol proses untuk menampilkan hasil klasifikasi status gizi stunting pada balita.
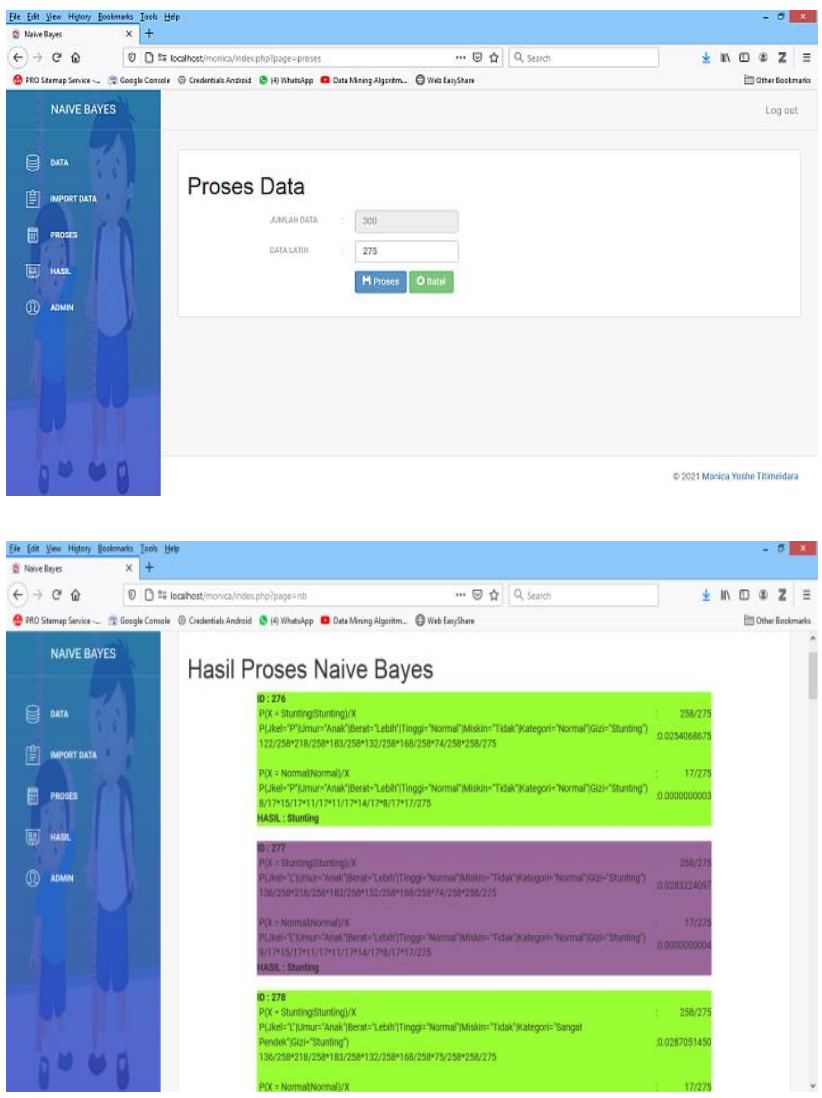

Gambar 5. Proses

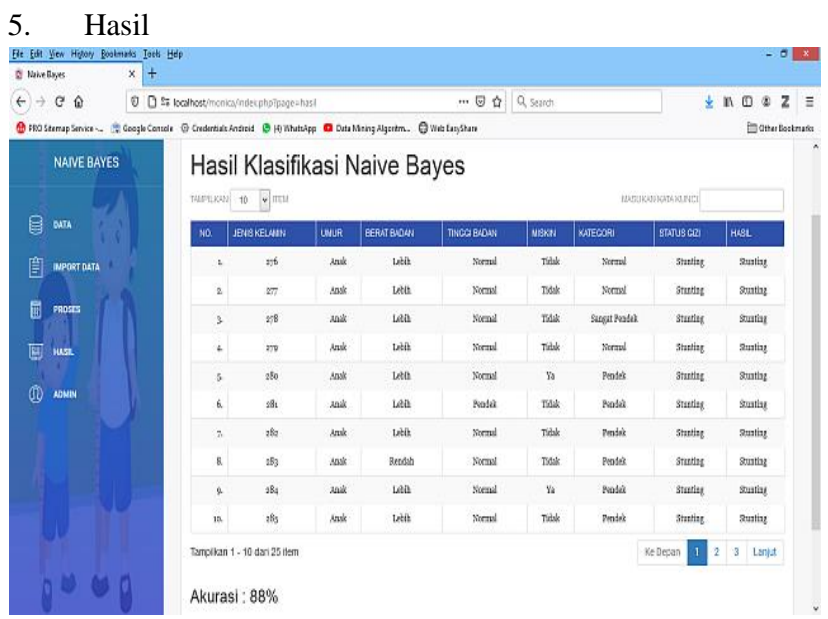

Gambar 6. Hasil

Gambar 6 menjelaskan tentang halaman hasil yang digunakan admin untuk melihat hasil klasifikasi status gizi stunting pada balita. Hasil akan ditampilkan dalam bentuk tabel yang berisi nomor, jenis kelamin, umur, berat badan, tinggi badan, miskin, kategori, status gizi dan hasil klasifikasi. Pada bawah tabel juga akan ditampilkan akurasi dari metode Naive Bayes Classifier menggunakan pengukuran confusion matrix. 
6.

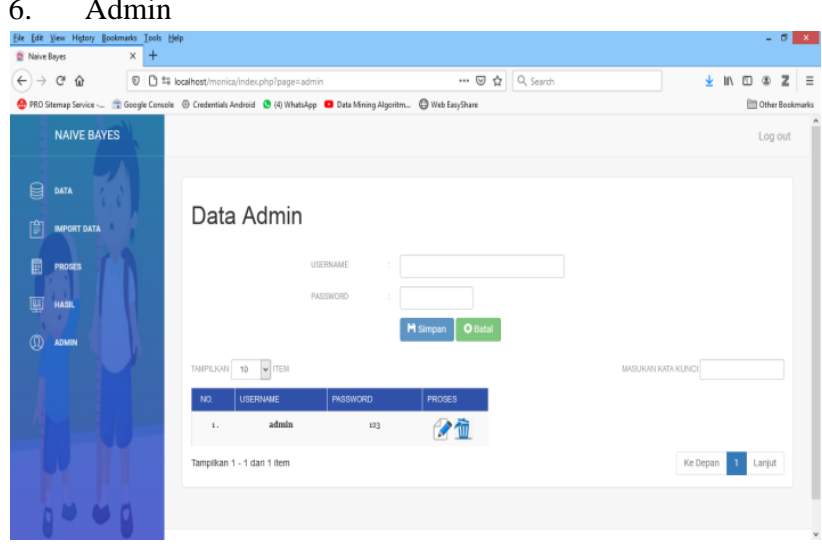

Gambar 7. Admin

Gambar 7 menjelaskan tentang halaman admin yang digunakan admin untuk mengelola data admin. Isi username, password kemudian tekan tombol simpan untuk menyimpan data admin ke tabel admin. Klik edit kemudian isi password dan tekan tombol simpan untuk mengubah data admin dari tabel admin. Klik hapus kemudian pilih oke untuk menghapus data admin dari tabel admin.

\section{KESIMPULAN DAN SARAN}

Berdasarkan penelitian, implementasi dan pengujian, maka dapat diambil kesimpulan bahwa Metode Naive Bayes Classifier dapat digunakan untuk klasifikasi status gizi stunting pada balita berdasarkan jenis kelamin, umur, berat badan, tinggi badan, status miskin dan kategori status gizi. Hasil akurasi dari Metode Naive Bayes Classifier dalam melakukan klasifikasi status gizi stunting pada balita adalah sebesar $88 \%$ dari 300 data yang dibagi menjadi 2 yaitu 275 data sebagai data latih dan 25 data sebagai data uji

\section{DAFTAR PUSTAKA}

[1] Ni'mah, K., \& Nadhiroh, S. R., (2015) Faktor yang Berhubungan Dengan Kejadian Stunting pada Balita. Jurnal Media Gizi Indonesia, 10(1) Januari-Juni, pp.13-19..

[2] Wahyudi, R., \& Sufriani., (2018) Pertumbuhan Dan Perkembangan Balita Stunting. JIM Fkep. 3(1), pp. 56-62.

[3] Kemenkes RI., (2020) Pedoman Gizi Seimbang. Direktorat Bina Gizi dan KIA. Jakarta.

[4] Anindita, P., (2012) Hubungan Tingkat Pendidikan Ibu, Pendapatan Keluarga, Kecukupan Protein dan Zinc dengan Stunting (Pendek) Pada Balita Usia 6-35 Bulan di Kecamatan Tembalang Kota Semarang. Jurnal Kesehatan Masyarakat. 1(2). pp.617-626

[5] Kusrini \& Luthfi, E.T., (2015) Algoritma Data Mining. Andi. Yogyakarta.

[6] Han, J. \& Kamber, M. (2016) Data Mining: Concept and Techniques, Third Edition. Morgan Kaufmann Publishers. Waltham

[7] Adriani, M. (2018) Pengantar Gizi. Kencana Prenada Media. Jakarta.
[8] Santosa, B. (2015) Data Mining: Teknik Pemanfaatan Data Untuk Keperluan Bisnis. GrahaIlmu. Yogyakarta.

[9] Hermawati, F.A. (2016) DataMining. Andi. Yogyakarta.

\section{BIODATA PENULIS}

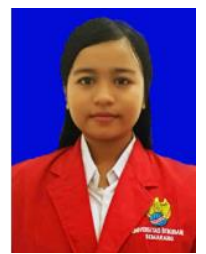

Monica Yoshe Titimeidara

Mahasiswa Universitas Stikubank Semarang

Program Studi Teknik Informatika

Email :222monicayoshe@gmail.com

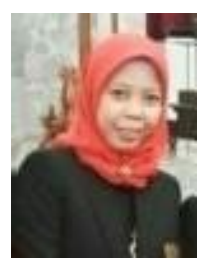

Wiwien Hadikurniawati, S.T., M.Kom.

Dosen Universitas Stikubank Semarang

Program Studi Teknik Informatika

Email : wiwien@edu.unisbank.ac.id 